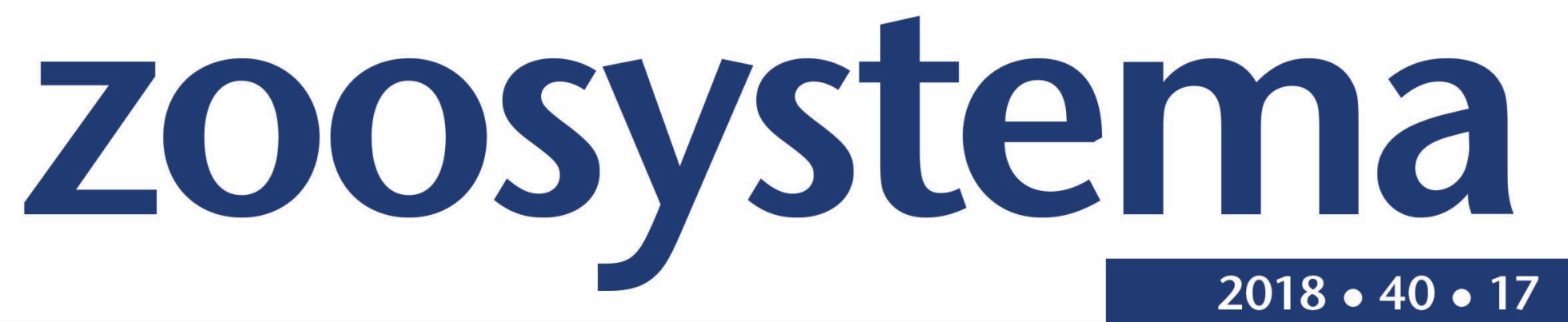

"OUR PLANET REVIEWED" 2015

LARGE-SCALE BIOTIC SURVEY IN MITARAKA, FRENCH GUIANA Edited by Julien TOUROULT
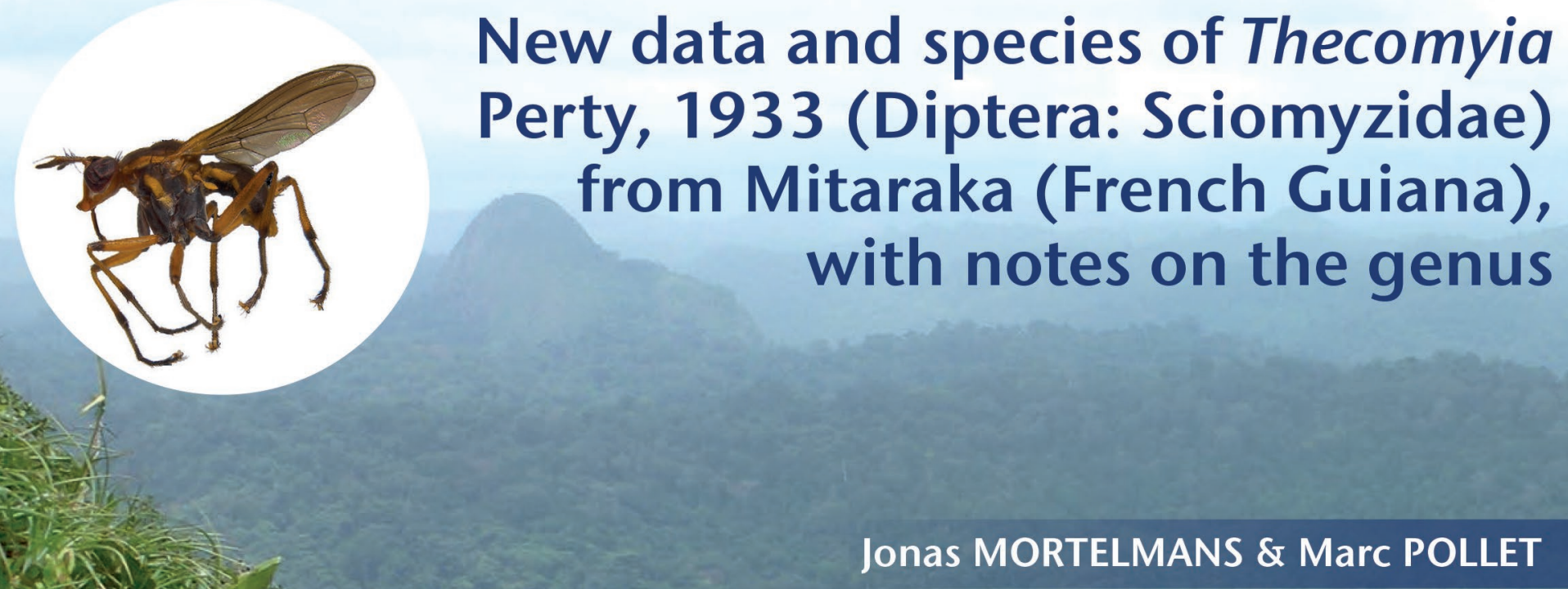

Jonas MORTELMANS \& Marc POLLET 
DiRECTEUR DE LA PUBlication: Bruno David

Président du Muséum national d'Histoire naturelle

RÉDACTRICE EN CHEF / EDITOR-IN-CHIEF : Laure Desutter-Grandcolas

AssistanTS DE RÉDACTION / AsSISTANT EDITORS: Anne Mabille (zoosyst@mnhn.fr), Emmanuel Côtez

Mise en PAge / PAgE LAYOUt: Anne Mabille

COMITÉ SCIENTIFIQUE / SCIENTIFIC BOARD:

James Carpenter (AMNH, New York, États-Unis)

Maria Marta Cigliano (Museo de La Plata, La Plata, Argentine)

Henrik Enghoff (NHMD, Copenhague, Danemark)

Rafael Marquez (CSIC, Madrid, Espagne)

Peter Ng (University of Singapore)

Gustav Peters (ZFMK, Bonn, Allemagne)

Norman I. Platnick (AMNH, New York, États-Unis)

Jean-Yves Rasplus (INRA, Montferrier-sur-Lez, France)

Jean-François Silvain (IRD, Gif-sur-Yvette, France)

Wanda M. Weiner (Polish Academy of Sciences, Cracovie, Pologne)

John Wenzel (The Ohio State University, Columbus, États-Unis)

COUVERTURE / COVER:

View of lowland rainforest and inselbergs from the inselberg Sommet en Cloche (Mitaraka mountains, French Guiana) (photo: Marc Pollet). In medaillion, male of Thecomyia chrysacra Marinoni \& Steyskal, 2003.

\author{
Zoosystema est indexé dans / Zoosystema is indexed in: \\ - Science Citation Index Expanded (SciSearch $\left.{ }^{\circledR}\right)$ \\ - ISI Alerting Services ${ }^{\circledR}$ \\ - Current Contents ${ }^{\circledR}$ / Agriculture, Biology, and Environmental Sciences ${ }^{\circledR}$ \\ - Scopus ${ }^{\circledR}$
}

Zoosystema est distribué en version électronique par / Zoosystema is distributed electronically by:

- BioOne ${ }^{\circledR}$ (http://www.bioone.org)

Les articles ainsi que les nouveautés nomenclaturales publiés dans Zoosystema sont référencés par /

Articles and nomenclatural novelties published in Zoosystema are referenced by:

- ZooBank ${ }^{\circledR}$ (http://zoobank.org)

Zoosystema est une revue en flux continu publiée par les Publications scientifiques du Muséum, Paris / Zoosystema is a fast track journal published by the Museum Science Press, Paris

Les Publications scientifiques du Muséum publient aussi / The Museum Science Press also publish:

Adansonia, Anthropozoologica, European Journal of Taxonomy, Geodiversitas, Naturae.

Diffusion - Publications scientifiques Muséum national d'Histoire naturelle

CP 41 - 57 rue Cuvier F-75231 Paris cedex 05 (France)

Tél. : 33 (0)1 40794805 / Fax: 33 (0)1 40793840

diff.pub@mnhn.fr / http://sciencepress.mnhn.fr

(c) Publications scientifiques du Muséum national d'Histoire naturelle, Paris, 2018

ISSN (imprimé / print): 1280-9551/ ISSN (électronique / electronic): 1638-9387

PHOTOCOPIES :

Les Publications scientifiques du Muséum adhèrent au Centre Français d'Exploitation du Droit de Copie (CFC), 20 rue des Grands Augustins, 75006

Paris. Le CFC est membre de l'International Federation of Reproduction Rights Organisations (IFRRO). Aux États-Unis d'Amérique, contacter le Copyright Clearance Center, 27 Congress Street, Salem, Massachusetts 01970.
PHOTOCOPIES:

The Publications scientifiques du Muséum adhere to the Centre Français d'Exploitation du Droit de Copie (CFC), 20 rue des Grands Augustins, 75006 Paris. The CFC is a member of International Federation of Reproduction Rights Organisations (IFRRO). In USA, contact the Copyright Clearance Center, 27 Congress Street, Salem, Massachusetts 01970. 


\title{
New data and species of Thecomyia Perty, 1833 (Diptera: Sciomyzidae) from Mitaraka (French Guiana), with notes on the genus
}

\author{
Jonas MORTELMANS \\ Entomology Unit, Royal Belgian Institute for Natural Sciences (RBINS), \\ Vautierstraat 29, B-1000 Brussels (Belgium) \\ jonasmortelmans@gmail.com (corresponding author) \\ Marc POLLET \\ Research Institute for Nature and Forest (INBO), Herman Teirlinckgebouw, \\ Havenlaan 88 bus 73, B-1000 Brussels (Belgium) \\ and Research Group Terrestrial Ecology (TEREC), Ghent University, \\ K. L.Ledeganckstraat 35, B-9000 Ghent (Belgium) \\ and Entomology Unit, Royal Belgian Institute for Natural Sciences (RBINS), \\ Vautierstraat 29, B-1000 Brussels (Belgium)
}

Submitted on 3 July 2017 | Accepted on 1 March 2018 | Published on 4 September 2018

KEY WORDS

Acalyptratae,

Sciomyzoidea,

French Guiana, geographical distribica, neotropical, snail-killing flies, survey, new species.

Mortelmans J. \& Pollet M. 2018. - New data and species of Thecomyia Perty, 1833 (Diptera: Sciomyzidae) from Mitaraka (French Guiana), with notes on the genus, in Touroult J., "Our Planet Reviewed" 2015 large-scale biotic Mitaraka (French Guiana), with notes on the genus, in Touroult J., "Our Planet Reviewed" 2015 large-scale biotic
survey in Mitaraka, French Guiana. Zoosystema 40 (17): 415-423. https://doi.org/10.5252/zoosystema2018v40a17. http://zoosystema.com/40/17

\section{ABSTRACT}

A new species of Thecomyia Perty, 1833, T. diederiki Mortelmans n. sp., is described from French Guiana, with diagnostic characters being the absence of anteromedial setae on the midfemur; an illdefined, tripartite, greyish mesonotal stripe; absence of upper fronto-orbital bristles; completely yellow mid- and hind femora; typical distiphallus bearing two long, curved acrophalli; absence of male anterior gonostyli; and large, triangular posterior gonostyli. All specimens were collected during the Mitaraka (French Guiana) 2015 survey that investigated an array of habitat types; the new species was encountered only in swamp forests. This discovery raises the number of species in this exclusively Neotropical genus to 13. An update of the relevant couplets in the key to Thecomyia in Marinoni et al. (2003) is presented to include the new species. New records of other species of Thecomyia from Costa Rica, French Guiana, and Brazil are given, with first records of Thecomyia lateralis (Walker, 1858) from Costa Rica, and first records of T. diederiki Mortelmans n. sp. and T. longicornis Perty, 1833 from French Guiana. 


\author{
MOTS CLÉS \\ Acalyptratae, \\ Sciomyzoidea, \\ Guyane, \\ Costa Rica, \\ distribution \\ néotropical, \\ enquête, \\ espèce nouvelle.
}

\begin{abstract}
RÉSUMÉ
Nouvelles données et une nouvelle espèce de Thecomyia Perty, 1833 (Diptera: Sciomyzidae) du Mitaraka (Guyane), et notes sur le genre.

Une nouvelle espèce de Thecomyia Perty, 1833, T. diederiki Mortelmans n. sp., est décrite de Guyane. Les caractères diagnostiques sont l'absence de setae antéromédiales sur le fémur 2 ; la bande mésonotale mal définie, tripartite et grisâtre; l'absence de soies fronto-orbitales supérieures; les fémurs 2 et 3 complètement jaunes; le distiphallus typique, portant deux acrophalles longs et courbés; chez les mâles, l'absence de gonostyles antérieurs; et des gonostyles postérieurs volumineux et triangulaires. Tous les spécimens ont été collectés pendant l'expédition Mitaraka 2015 (Guyane) qui a étudié un éventail de types d'habitats; la nouvelle espèce a été rencontrée seulement dans les forêts marécageuses. Cette découverte augmente le nombre d'espèces dans ce genre strictement néotropical à 13. Les couplets concernés dans la clé des Thecomyia de Marinoni et al. (2003) sont mis à jour pour inclure la nouvelle espèce. Des signalisations nouvelles d'autres espèces de Thecomyia sont données pour le Costa Rica, la Guyane, et le Brésil. Sont mentionnées pour la première fois Thecomyia lateralis (Walker, 1858) du Costa Rica, T. diederiki Mortelmans n. sp. et T. longicornis Perty, 1833 de Guyane.
\end{abstract}

\section{INTRODUCTION}

Thecomyia Perty, 1833 is a genus of snail-killing flies restricted to Central and South America (Knutson \& Vala 2011). Adults are recognised by the combination of a narrow, conical face; a completely retractable proboscis; strongly reduced palpi; and strongly reduced body setae (Marinoni \& Mathis 2000; Marinoni et al. 2003). Although the genus is recognised easily, the currently known species of Thecomyia are morphologically very similar, and diagnostic characters are found mainly in the male postabdomen; females sometimes can be determined by a combination of external characters, association with males, and geographical range.

Until 2003, only four species of Thecomyia were known: T. limbata (Wiedemann, 1819), T. longicornis Perty, 1833, T. lateralis (Walker, 1858), and T. trilineata Hendel, 1932. In 1968, G. C. Steyskal (U.S. Department of Agriculture, National Museum of Natural History, Washington, DC, USA [USDA]) started taxonomic research on Thecomyia to support life cycle studies being conducted by J. Abercrombie and C. O. Berg of Cornell University (Ithaca, New York, USA). Steyskal examined type specimens, figured male postabdomens of most species and prepared a preliminary key. Steyskal retired in 1979 and passed the unpublished manuscript on to L. V. Knutson (USDA), who drafted a generic description of Thecomyia and redescribed T. limbata. Knutson \& Carvalho (1989) referred to this unpublished manuscript as "Steyskal \& Knutson in preparation," noting that it included descriptions of 11 undescribed species of Thecomyia. Work on this unpublished manuscript was resumed by $\mathrm{L}$. Marinoni (Department of Zoology, Universidade Federal do Paraná, Brazil), and finally published as Marinoni et al. (2003). They described nine new species and synonymised T. trilineata with $T$. lateralis, thus setting the number of species in the genus at 12 .

In Thecomyia only the biology of Thecomyia limbata is known, thanks to efforts by Abercrombie \& Berg (1975), who reared the species through its complete life cycle. Larvae of this species are predaceous on non-operculate freshwater snails, whereas adults might be active nectar feeders on flowers, as is suggested by the long haustellum and proboscis (Knutson \& Vala 2011). The latter authors also suggested that the general brown-and-yellow body color of Thecomyia, which is similar to that of many predatory wasps, could be a case of Batesian mimicry used to avoid predation when visiting flowers.

During separate surveys in French Guiana and Costa Rica in 2015, researchers collected specimens of Thecomyia, including one undescribed species. In the present paper, we provide a description of Thecomyia diederiki Mortelmans n. sp., update the relevant couplets of the key in Marinoni et al. (2003) to include the new species of Thecomyia, and report on and discuss the results of the two above-mentioned surveys.

\section{MATERIAL AND METHODS}

Two separate entomological surveys conducted in 2015 collected specimens of Thecomyia (Fig. 1). The first survey was the "Our Planet Reviewed" or "La Planète revisitée" Guyane 2014-2015 expedition, also known as the Mitaraka 2015 survey, that was conducted in the Parc amazonien de Guyane, French Guiana (Pollet et al. 2014; Pascal et al. 2015; Touroult et al. 2018). This program, cooperatively conducted by the Muséum national d'Histoire naturelle (MNHN) and Pro-Natura International (both in France), aimed at rehabilitating taxonomic research that focuses on the largely neglected components of global biodiversity, specifically invertebrates in aquatic, marine, and terrestrial habitats. During this expedition, researchers investigated the mostly biologically unknown and nearly uninhabited Mitaraka Mountains in the southwesternmost corner of French Guiana, directly bordering Suriname and Brazil. The area consists primarily of tropical lowland rain forest with scattered inselbergs (Fig. 2). Between 22.II and 27.III.2015, two teams of about 


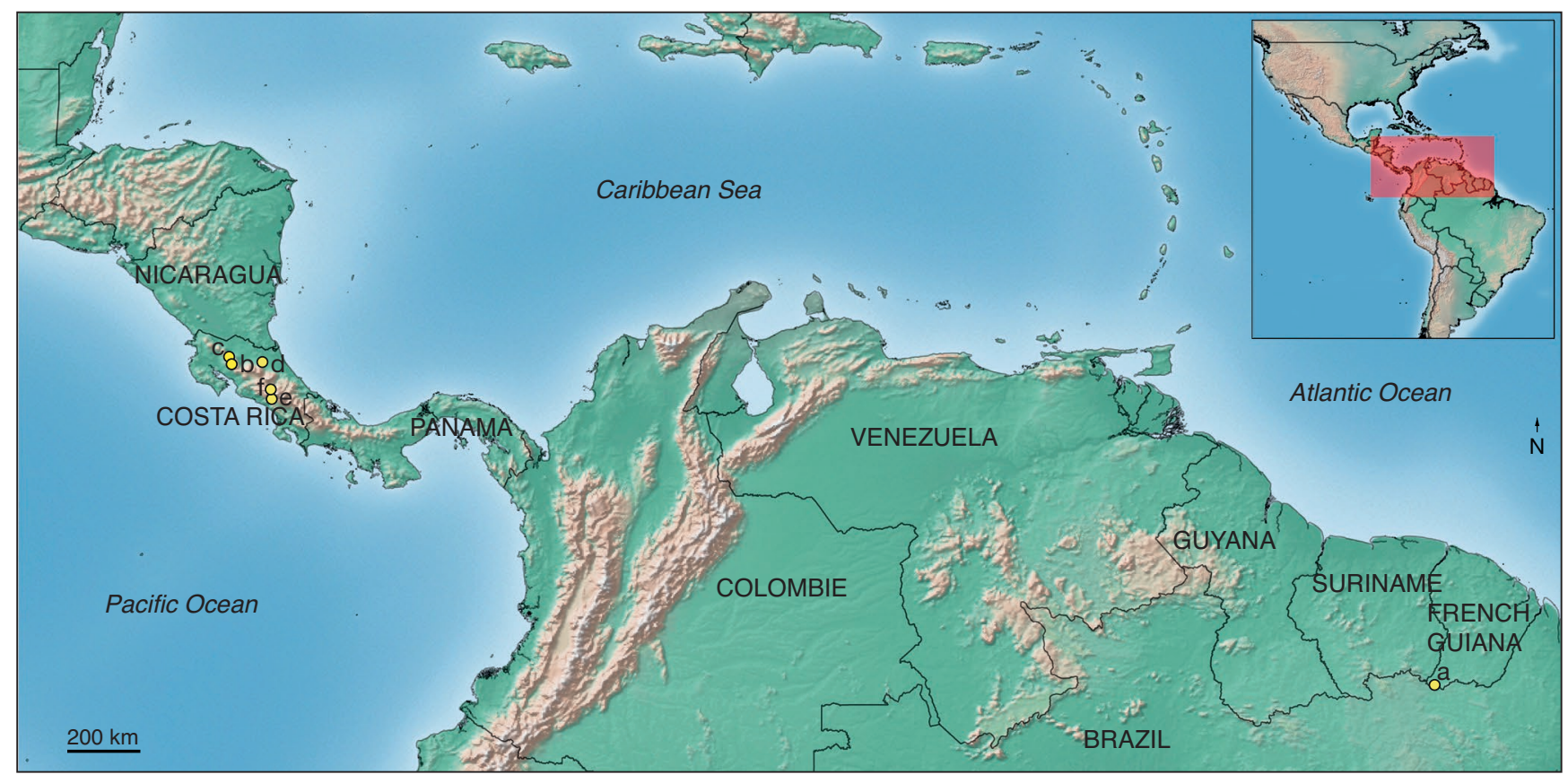

FIG. 1. - Sites in Costa Rica and French Guiana sampled for Diptera during entomological surveys in 2015: a, Mitaraka (French Guiana); b, Estación Biológica Monteverde (Santa Elena); c, rainforest of Chalet Nicholas near Parque Tenório Reserva (Nuevo Arenal); d, OTS-Estación Biológica La Selva (near Puerto Viejo de Sarapiqui); e, Dantica Reserva Forestal Privada - Los Santos Reserva Forestal and the Savegre Reserva Natural (San Gerardo de Dota); f, Parque Nacional Tapantí (near Orosi).

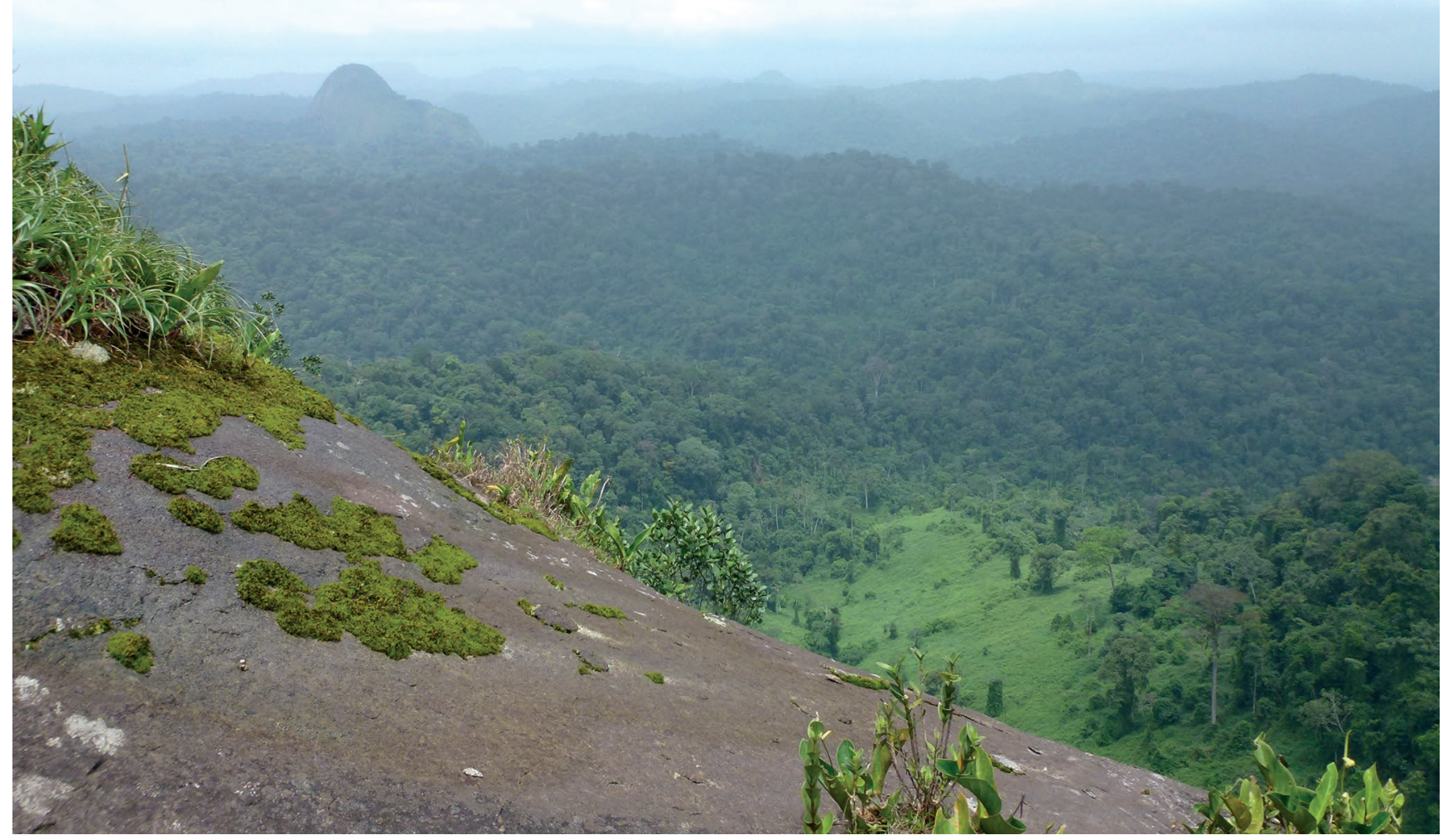

FIG. 2. - View of lowland rainforest and inselbergs from the inselberg Sommet en Cloche (Mitaraka mountains, French Guiana) (photo: Marc Pollet). 


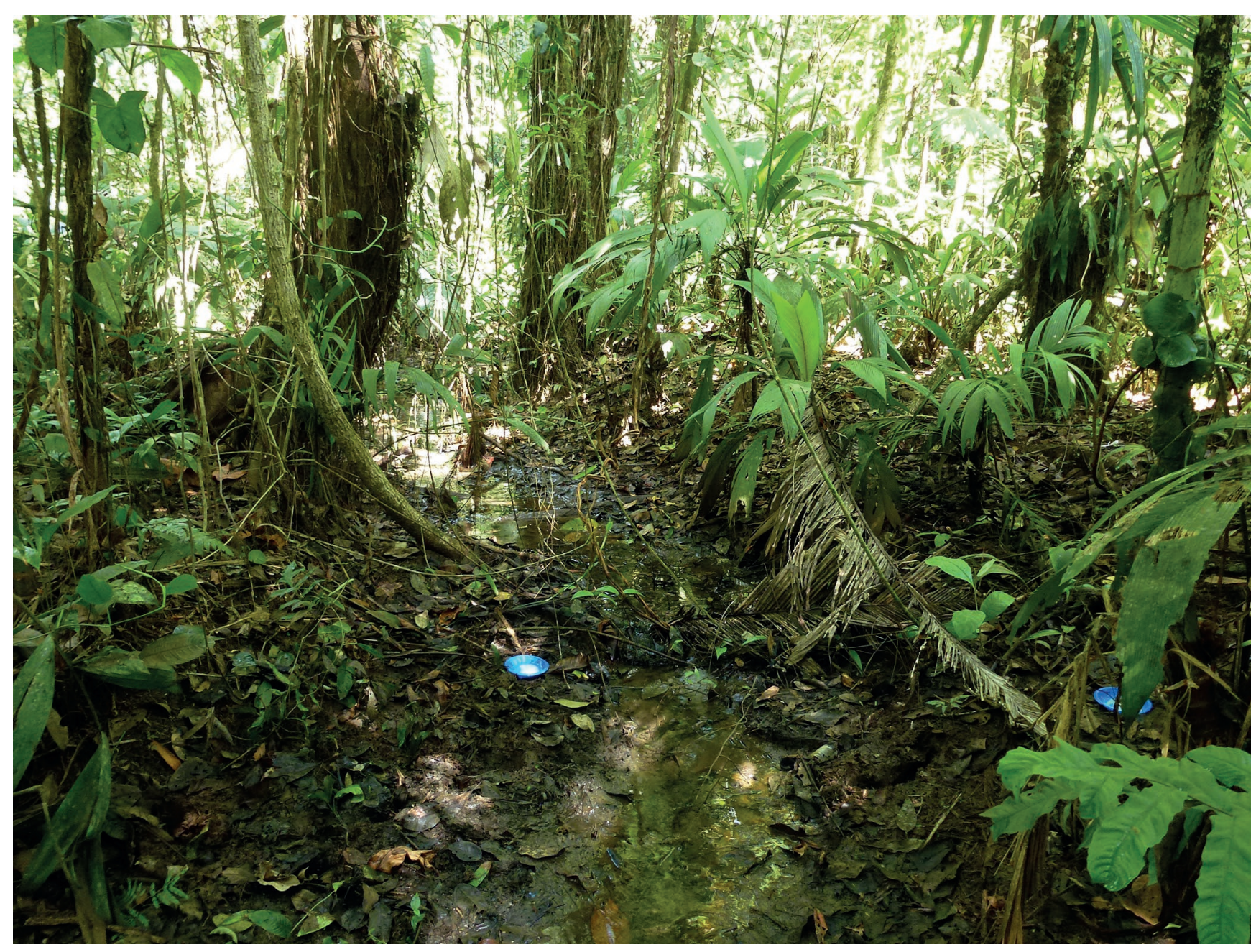

FIG. 3. - Blue pan traps in swamp site LS-SW2 in OTS - Estación Biológica La Selva (Costa Rica) (photo: Marc Pollet).

30 researchers explored the area. A third, smaller team returned to the site from 12 to 20.VIII.2015. One of us (MP) acted as coordinator of the collected Diptera and was also the only Diptera worker actively involved in this expedition.

Invertebrates were sampled near the base camp, on the drop zone (an area near the base camp that had been clear cut to allow helicopters to land) and, in particular, along four trails of about $3.5 \mathrm{~km}$ each that started from the base camp and led in four different directions. Sampling for invertebrates was most intense during the first survey (22.II-11.III.2015), during which more than 21 different collecting methods were applied and with a total of 401 traps operational within a $1-\mathrm{km}^{2}$ perimeter (Touroult et al. 2018). This array consisted primarily of blue, yellow and white pan traps $(n=280)$, Charax butterfly traps $(n=50)$, SLAMs $(n=32)$, flight intercept traps (FIT, $\mathrm{n}=13)$ and butterfly banana traps $(\mathrm{n}=12)$. A total of 223 invertebrate samples (often pooled yields of different traps of the same type) were examined, including 93 sweep net samples and 27 and 62 samples collected by SLAM and colored pan traps ( 24 blue, 22 yellow, and 16 white traps), respectively. All collected material was stored in $70 \%$ ethanol during the expedition, with the sciomyzid fraction being pinned directly from ethanol about 12 months later in the laboratory. Specimens collected during the Mitaraka 2015 survey were deposited in MNHN, and in JM's personal collection, according to an agreement between JM and MNHN.

The second survey was conducted in Costa Rica between 29.III and 18.IV.2015, mainly by MP, with assistance from Anja De Braekeleer, his wife. Five main locations in five different provinces in the north and the centre of Costa Rica were investigated: Estación Biológica Monteverde (Puntarenas Province); a rain-forest adjacent to Parque Tenório Reserva near Chalet Nicholas, Nuevo Arenal (Guanacaste Province); Organization for Tropical Studies (OTS), Estación Biológica La Selva, near Puerto Viejo de Sarapiquí (Heredia Province); the Dantica Reserva Forestal Privada - Los Santos Reserva Forestal and the Savegre Reserva Natural at San Gerardo de Dota (San José Province); and the Parque Nacional Tapantí near Orosí (Cartago Province)(Fig. 1). At each of these locations, 4-6 sampling sites in rain-forest habitat and on river-banks were selected for sampling, mainly by pan traps (Fig. 3). In 1-2 sampling sites per location, one Malaise trap was installed together with one unit of 10 blue, 10 white and 10 yellow pan traps. In the remaining sampling sites, one unit of 10 yellow 
pan traps was operational. In all sampling sites, flies were also actively collected by use of sweep nets. Trapping was conducted for 3-4 days at each location except at Nuevo Arenal, where three sites were trapped for a period of 16 days. Yields of pan traps of the same unit during a single sampling period were pooled into a single sample. A total of 199 samples were ultimately gathered, consisting of 136 sweep net samples and eight, 12, and 34 pooled samples of blue, white and yellow pan traps, respectively. All specimens were stored in $70 \%$ ethanol. Samples were later sorted in the home laboratory of MP, who transferred all specimens of Sciomyzidae to JM for examination. Specimens were ultimately deposited in the INBio entomological collections of the Universidad de Costa Rica, San José, and in JM's personal collection.

All specimens of Sciomyzidae collected in both surveys were examined by JM. Morphological analyses and diagnosis of the specimens were performed with a Novex AR-Zoom Stereomicroscope, with $40 \times$ magnification. Photographs of the specimens were taken by use of a Leica M205 stereomicroscope, with up to $160 \times$ magnification, at the LifeWatch observatory, VLIZ. In the descriptions that follow, the size of the eye is measured from the ocellar tubercle to the lower eye margin. Fore-, mid- and hind legs are indicated as I, II and III. Abdominal tergites and sternites are indicated as ' $\mathrm{T}$ ' and 'ST', respectively; 1-8 in the description of the abdominal segments refers sequentially from basal (1) to caudal (8) segments.

\section{ABBREVIATIONS}

Institutions

INBio INBio entomological collections of the Universidad de Costa Rica, San José;

MNHN Muséum national d'Histoire naturelle, Paris;

RBINS Royal Belgian Institute of Natural Sciences, Brussels;

VLIZ Flanders Marine Institute, Oostende.

Private collection

Coll. JM Jonas Mortelmans' private collection, Ghent.

\section{RESULTS}

Family SCIOMYZIDAE Macquart, 1846

Genus Thecomyia Perty, 1833

Thecomyia diederiki Mortelmans n. sp. (Figs 4B, D, F; 5)

\section{urn:Isid:zoobank.org:act:A7CAD602-B9CB-40E1-ABDC-71C4D23B9434}

Type MATERIAL. - Holotype. $10^{\prime \prime}$, French Guiana: Mitaraka, site MIT-C-RBF2, $02^{\circ} 14^{\prime} 03.4^{\prime \prime N}, 54^{\circ} 26^{\prime} 53.0^{\prime \prime} \mathrm{W}, 299 \mathrm{~m}$, on vegetation along muddy trail and in swamp, 3.III.2015, sweep net, MP leg., sample code: MITARAKA/058 (sorted by MP, 2015) (top label); "La Planète Revisitée - MNHN / PNI Guyane 2015 - APA-973-1” (mid label); "Thecomyia diederiki n. sp. Mortelmans. HT" (bottom label, green). MNHN (pinned specimen, abdomen removed, dissected, stored in microvial containing glycerine on same pin as specimen), with accession number MNHN-ED-ED10596.

Paratypes. French Guiana: $10^{\circ}$, Mitaraka, site MIT-C-RBF1, $02^{\circ} 14^{\prime} 10.8^{\prime \prime} \mathrm{N}, 54^{\circ} 26^{\prime} 49.5^{\prime \prime} \mathrm{W}, 258 \mathrm{~m}$, tropical wet forest ( = swamp forest, "bas fond"), 24-27.II.2015, yellow pan traps, MP leg., sample code: MITARAKA/122 (sorted by MP, 2015) (top label); "La Planète Revisitée - MNHN / PNI Guyane 2015 - APA-973-1" (mid label); "Thecomyia diederiki n. sp. Mortelmans. PT" (bottom label, green); MNHN (pinned specimen, abdomen removed, dissected, stored in microvial containing glycerine on same pin as specimen), with accession number MNHN-ED-ED10597; 1 0", Mitaraka, site MIT-C-RBF2, 02 $14^{\circ} 03.4^{\prime \prime} \mathrm{N}, 54^{\circ} 26^{\prime} 53.0^{\prime \prime} \mathrm{W}, 299 \mathrm{~m}$, on vegetation along muddy trail and in swamp, 6.III.2015, SW, MP leg., sample code: MITARAKA/072 (sorted by MP, 2015) (top label); "La Planète Revisitée - MNHN / PNI Guyane 2015 - APA-973-1" (mid label); "Thecomyia diederiki n. sp. Mortelmans. PT" (bottom label, green). Coll. JM, intact, dry, pinned specimen.

TYPE LOCALITY. - Mitaraka mountain range in southwesternmost French Guiana.

DiSTRIBUTION. - The species is known only from the type locality.

ETYMOLOgY. - The species is named in honour of Diederik Volckaert, a good friend of the first author and an excellent collector of Sciomyzidae.

DiAgNOSIS. - Diagnostic external characters of T. diederiki Mortelmans n. sp. include the absence of anteromedial setae on midfemur (Fig. 4D); an ill-defined, tripartite and greyish mesonotal stripe (Fig. 4D); absence of upper fronto-orbital setae (Fig. 4F); a typical distiphallus; and completely yellow femora II-III (Fig. 4B, D). Thecomyia diederiki Mortelmans n. sp. appears similar to T. lateralis, T. mathisi Marinoni, 2003, and especially T. bonattoi Marinoni \& Steyskal, 2003 in respect to the distiphallus, bearing 2-3 long, curved acrophalli and in the absence of the male anterior gonostyli. Thecomyia diederiki Mortelmans n. sp. can be differentiated easily from these species by the large, triangular posterior gonostyli. Furthermore, the two large acrophalli (three in T. bonattoi) on the distiphallus are unique, being similar to each other in size and shape, in contrast to the unequal prolongations on the acrophalli in the other three species (Fig. 5).

\section{DESCRIPTION}

Male

Measurements. Body length $5.5 \mathrm{~mm}$, wing length $4.5 \mathrm{~mm}$.

Head. Ground color brownish, with only fronto-orbital spot velvety black, and a triangular black spot in the middle of face. Fronto-orbital spot large, triangular with rounded corners, width approximately $1 / 3$ width of frons. Oral margin in lateral view slightly protuberant. Rostrum $0.6 \times$ as high as eye. Head mainly shiny, with a heavily dusted stripe on frons adjacent to the eye, extended ventrally to just below the eye. White microtomentose infra-ocular marking extended approximately $1 / 2$ distance to the oral margin. Ocellar triangle slightly protuberant. Upper fronto-orbital seta absent. Only four setae on head: one pair of inner and one pair of outer vertical setae. Palpus absent, reduced to a few black hairs. Proboscis elongated, dark yellow. Antenna yellow, basal flagellomere slightly darker. Arista subbasal, yellow, bearing very long, white hairs.

Thorax and abdomen. Body brown with two obvious golden yellow stripes: one longitudinal stripe lateral to scutum, one dorsoventral stripe from anepisternum to katepisternum. Scutellum almost completely yellow, with anterior corners slightly darker to brown. Medial mesonotonal stripe very 
obscure, slightly lighter than surrounding area, greyish. Thoracic chaetotaxy: 2 notopleurals, 1 supra-alar, 1 postalar and 1 pair of scutellar setae. Pleura bare. Halter completely yellow. Katatergite yellow. Abdomen concolorous with thorax, both sternites and tergites dull brownish with only lateral margin of tergites golden yellow, tergites densely and evenly setulose.

Wing. Slightly and evenly infuscated brownish, slightly yellow at base. Wing venation typical for Thecomyia: veins $\mathrm{R}_{4+5}$ and $\mathrm{M}_{1}$ parallel to apex, crossvein $\mathrm{dm}-\mathrm{m}$ straight; $\mathrm{CuA}+\mathrm{CuP}$ complete to margin; $\mathrm{CuA}$ truncate; anal lobe not expanded.

Legs. Coxae and trochanters brown, coxa I with strong golden pubescence, coxae and trochanters II-III only slightly pubescent. Femora and tibiae completely yellow, with femur I slightly darker at apex. Femur I with only small setulae, evenly distributed, without setae. Femora II-III with small setulae along entire length and with 5-7 large setae on anteroventral and posteroventral surface near apex, arranged in two parallel rows. Tarsi completely yellow.

Genital apparatus. ST6 asymmetrical. Left 7 th spiracle below synsternite $7+8$, situated on the membrane next to T7. Anterior surstylus absent. Posterior surstylus large and elongate, with posterior end in lateral view bifid and pointed (Fig. 5D). Anterior part of posterior surstylus in lateral view small and slightly protruding beyond edge of epandrium, resembling an anterior surstylus. Cercus surpassing edge of epandrium, triangular. Hypandrium in lateral view with dorsal margin straight and ventral margin curved (Fig. 5C). Membranous ridge very large, obvious and visible (Fig. 5A). Distiphallus with two distinct and conspicuous processes, similar to each other in shape and size, projecting ventrally. Ejaculatory apodeme broad at apex, similar in size to basiphallus. Membranous stripes of hypandrium very wide. Phallopodeme broad, rigid. Epiphallus shorter than phallopodeme, with deep notch, covering base of distiphallus. Basiphallus large, apical tip curved dorsally and with small, subapical protuberance (Fig. 5A).

\section{Thecomyia chrysacra}

Marinoni \& Steyskal, 2003

Thecomyia chrysacra Marinoni \& Steyskal in Marinoni et al., 2003: 23.

Material eXAmined. - Costa Rica. 1 Ơ⿱ $^{7}$. Heredia, OTS - Estación Biológica La Selva, near Puerto Viejo de Sarapiquí, site LS-SW1 along Camino Circular Cercano (CCC), 10²5'28.8”N, $84^{\circ} 00^{\prime} 34.5^{\prime \prime W}, 35 \mathrm{~m}$, swamp forest, 5-8.IV.2015, yellow pan traps, MP \& Anja De Braekeleer leg., sample code: CR/2015/171/MP. INBio (pinned specimen, abdomen removed, dissected, stored in microvial containing glycerine on same pin as specimen) (Fig. 4A, C, E). 1 ९, OTS-Estación Biológica La Selva, near Puerto Viejo de Sarapiquí, site LS-SW2 along Sendero Suampo (SUA), $10^{\circ} 25^{\prime} 11.7^{\prime \prime} \mathrm{N}$, $84^{\circ} 00^{\prime} 31.3^{\prime \prime W}, 48 \mathrm{~m}$, swamp forest, 5-8.IV.2015, yellow pan traps, MP \& Anja De Braekeleer leg., sample code: CR/2015/173/MP. Coll. JM, intact, dry, pinned specimen.

\section{Thecomyia lateralis (Walker, 1858)}

Tetanocera lateralis Walker, 1858: 221 (type locality: "Valley of Amazon").

Thecomyia trilineata Hendel, 1932: 98 (type locality: Pozo del Tigre, Bolivia). - Marinoni et al. 2003: 16 (synonymy with T. lateralis).

Thecomyia lateralis - Steyskal 1966: 447 (type examination, generic combination). - Knutson et al. 1976: 13 (Neotropical catalogue).

Material eXAmined. - Costa Rica. 3 o', Heredia, OTS - Estación Biológica La Selva, near Puerto Viejo de Sarapiquí, site LS-SW1 along Camino Circular Cercano (CCC), $10^{\circ} 25^{\prime} 28.8^{\prime \prime} \mathrm{N}, 84^{\circ} 00^{\prime} 34.5^{\prime \prime W}$, $35 \mathrm{~m}$, swamp forest, 5-8.IV.2015, yellow pan traps, MP \& Anja De Braekeleer leg., sample code: CR/2015/171/MP (abdomen removed, dissected, stored in microvial containing glycerine on same pin as specimen), INBio, pinned specimens. $10^{7}$ (same data), deposited as an intact, dry, pinned specimen, coll. JM. 1 \&, OTS-Estación Biológica La Selva, near Puerto Viejo de Sarapiquí, site LS-SW2 along Sendero Suampo (SUA), 10²5'11.7”N, 8400'31.3”W, 48 m, swamp forest, 5-8.IV.2015, yellow pan traps, MP \& Anja De Braekeleer leg., sample code: CR/2015/173/MP, INBio, pinned specimens.

\section{REMARK}

This is the first record of T. lateralis from Costa Rica.

\section{Thecomyia limbata (Wiedemann, 1819)}

Tetanocera limbata Wiedemann, 1819: 54 (type locality: “Brasil”); 1830: 584 (citation).

Thecomyia limbata - Frey 1918: 24 (generic combination). - Hendel 1932: 98 (suggested synonym with Thecomyia longicornis). Abercrombie \& Berg 1975: 355-368 (biology and description of immature stages). - Knutson et al. 1976: 13 (Neotropical catalogue). — Marinoni et al. 2003: 191 (generic revision).

Material eXAmined. - Brazil. 1 ơ, 1 \%, Araçatuba Sáo Paulo, Rio Jacaregatinga, 1-31.X.1961, Lane \& Rabello leg., RBINS.

\section{REMARK}

New distribution record of T. limbata from Brazil is provided above, based on material located in the RBINS collection. The two specimens were labelled "Thecomyia sp.;" examination proved the specimens to belong to T. limbata.

\section{Thecomyia longicornis Perty, 1833}

Thecomyia longicornis Perty, 1833: 189 (designated as type species; type locality: "Amazon", Brazil). — Rondani 1868: 79-80, (redescription). - Hendel 1932: 98 (suggested synonym with Thecomyia limbata). - Curran 1934: 458 (distribution). - Abercrombie \& Berg 1975 (revalidation of name). - Knutson et al. 1976: 13 (Neotropical catalog). - Knutson \& Carvalho 1989 (seasonal distribution). - Marinoni \& Mathis 2000: 209 (cladistic analysis). - Marinoni et al. 2003: 14 (generic revision).

Material eXAmined. - French Guiana. $10^{\prime \prime}$, Mitaraka, site MITDZ-RBF2, $02^{\circ} 13^{\prime} 59.3^{\prime \prime} \mathrm{N}, 54^{\circ} 27^{\prime} 00.3^{\prime \prime W}, 283 \mathrm{~m}$, tropical wet forest (bas fond), 28.II-5.III.2015, yellow pan traps, MP leg., sample code: MITARAKA/176 (abdomen removed, dissected, stored in microvial containing glycerine on same pin as specimen), MNHN, pinned specimen with accession number MNHN-ED-ED10598. 1 ơ, Mitaraka, 

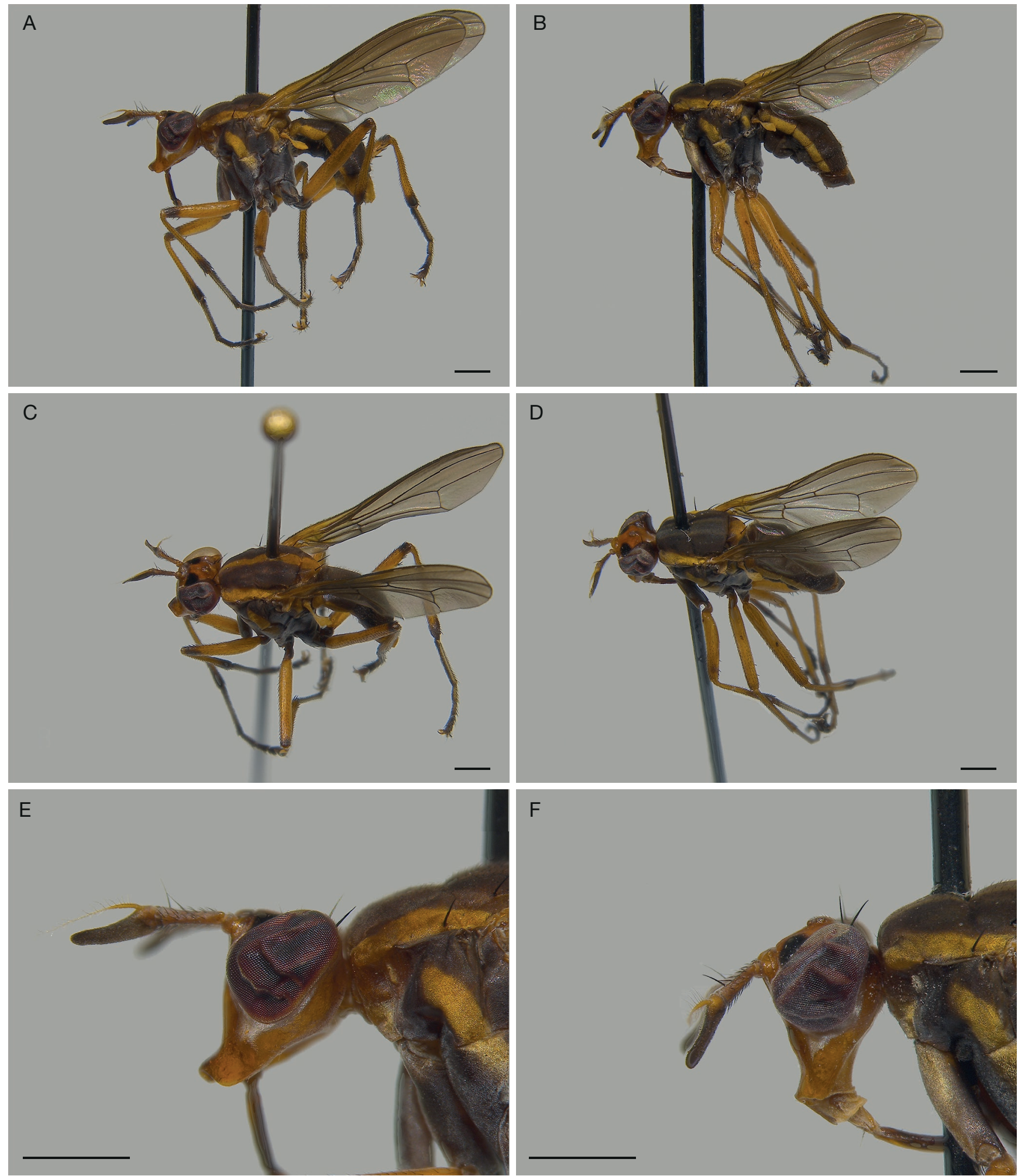

FIG. 4. - A, C, E, ơ Thecomyia chrysacra Marinoni \& Steyskal, 2003: A, habitus, lateral view; C, habitus, dorsolateral view; E, head, lateral view; B, D, F, ơ holotype of Thecomyia diederiki Mortelmans n. sp.; B, habitus, lateral view; D, habitus, dorsolateral view; F, head, lateral view. Scale bars: 1 mm.

site MIT-D-RBF, $02^{\circ} 13^{\prime} 58.8^{\prime \prime} \mathrm{N}, 54^{\circ} 27^{\prime} 07.5^{\prime \prime} \mathrm{W}, 317 \mathrm{~m}$, on vegetation along muddy trail and in swamp, 6.III.2015, sweep net, MP leg., sample code: MITARAKA/075, deposited as an intact, dry, pinned specimen, coll. JM. 1 \%, Mitaraka, site MIT-DZ-RBF2, $02^{\circ} 13^{\prime} 59.3^{\prime \prime} \mathrm{N}$, $54^{\circ} 27^{\prime} 00.3^{\prime \prime} \mathrm{W}, 283 \mathrm{~m}$, tropical wet forest (bas fond), 28.II-5.III.2015, yellow pan traps, MP leg., sample code: MITARAKA/176, MNHN, pinned specimen with accession number MNHN-ED-ED10599.

\section{REMARK}

This is the first record of T. longicornis from French Guiana. 

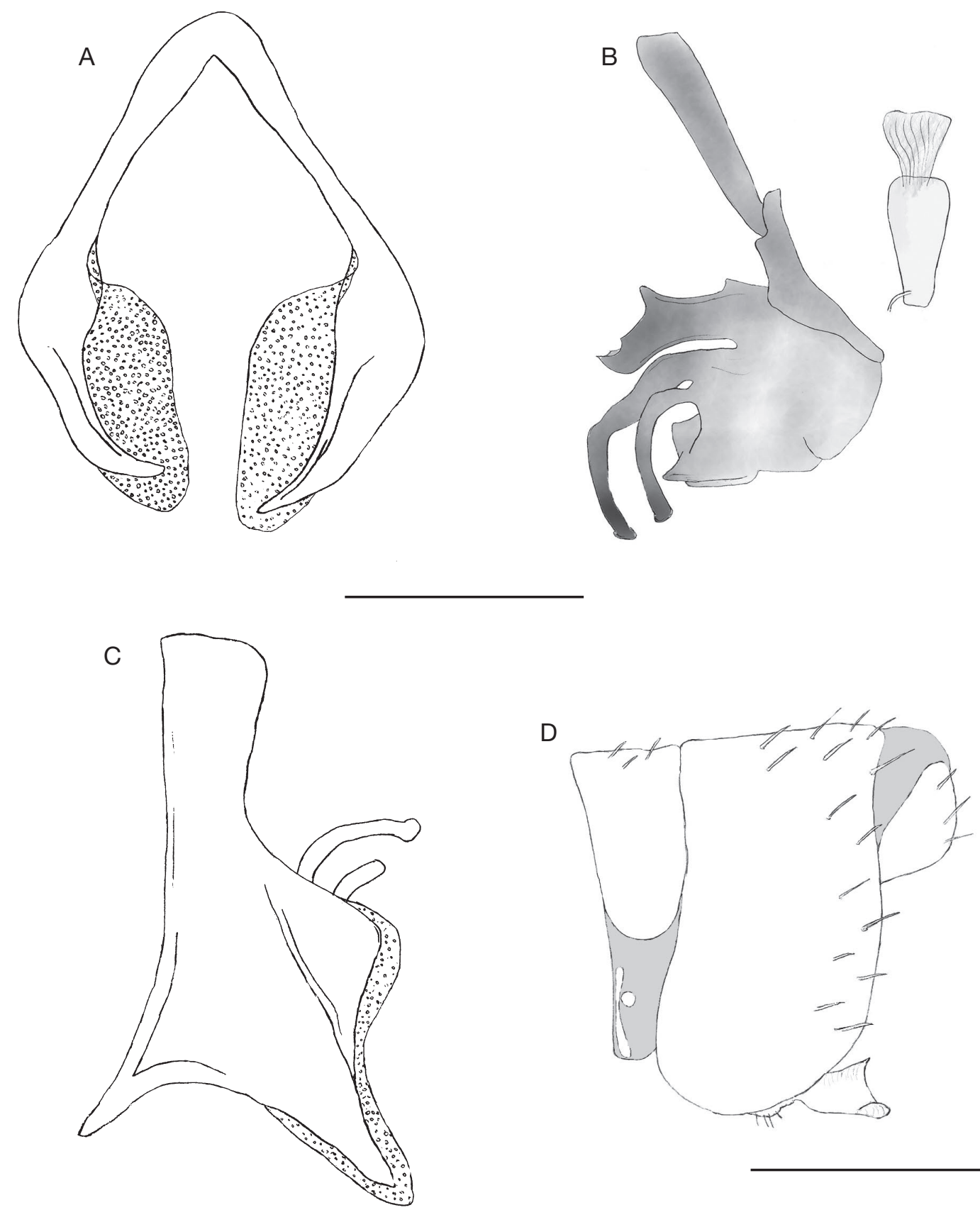

FIG. 5. - Paratype ơ Thecomyia diederiki Mortelmans n. sp.: A, hypandrium, dorsal view; B, phallopodeme, distiphallus, and acrophalli, lateral view; C, hypopygium, lateral view; $\mathbf{D}$, hypandrium, lateral view. Scale bars: A-C, $0.2 \mathrm{~mm} ; \mathrm{D}, 0.4 \mathrm{~mm}$.

Key to THECOMYIA PerTy, 1833

The new Thecomyia species is described on the basis of males only. Male Thecomyia can be identified by use of the key to species by Marinoni et al. (2003). To include T. diederiki Mortelmans n. sp., couplet 10 should be adjusted as follows:

10. Distiphallus with acrophallus strongly coiled (Marinoni et al. 2003: fig. 7), acrophallus with one or two pro-

— Distiphallus with acrophallus not strongly coiled, projecting ventrally, acrophallus with three processes .... 11

$10^{\prime}$. Posterior surstylus rounded; acrophallus with one strongly coiled process T. lateralis (Walker, 1858)

- Posterior surstylus bifid with apex acute, acrophallus with two strongly coiled, similar processes T. diederiki Mortelmans n. sp. 


\section{DISCUSSION}

Habitat affinity in Thecomyia is unknown. In both French Guiana and Costa Rica, Thecomyia species were encountered exclusively in swamp forests. In French Guiana, specimens were collected in both sweep net and yellow pan traps at three different swamp forest ("bas fonds") sites between 258 and $306 \mathrm{~m}$ a.s.l. In Costa Rica, specimens were collected only in yellow pan traps in two swamp forest sites at OTS-Estación Biológica La Selva. None of the other sites in Costa Rica between $34 \mathrm{~m}$ and $3.390 \mathrm{~m}$ a.s.l., often near rivers, nor any of the other collecting methods (e.g. blue or white pan traps) yielded Thecomyia specimens. These observations suggest that the use of yellow pan traps placed in swamp forests might be a suitable method for detecting the presence of Thecomyia.

\section{Acknowledgements}

Specimens of Thecomyia longicornis and T. diederiki Mortelmans n. sp. were collected during the "Our Planet Reviewed" Guyane-2015 expedition in the Mitaraka range, in the core area of the Parc amazonien de Guyane, organised by the MNHN and Pro-Natura International. The expedition was funded by the European Regional Development Fund (ERDF), the Conseil régional de Guyane, the Conseil général de Guyane, the Direction de l'Environnement, de l'Aménagement et du Logement and by the ministère de l'Éducation nationale, de l'Enseignement supérieur et de la Recherche. It was executed in collaboration with the Parc amazonien de Guyane and the Société entomologique Antilles-Guyane (http://insectafgseag.myspecies.info/fr). We are greatly indebted to Mrs Anja De Braekeleer, who provided MP with assistance during field work in Costa Rica. Many thanks are also due to Pol Limbourg, Jérôme Constant, and Wouter Dekoninck (all RBINS) for kindly showing JM around in the entomological collection. We thank Dr Luciane Marinoni for kindly providing the photograph of the male distiphallus of $T$. lateralis. We also thank the LifeWatch observatory as part of the Flemish contribution to the LifeWatch ESFRI by Flanders Marine Institute for the use of their binocular microscope. We are very grateful to Dr Lloyd Knutson, Gaeta, Italy; Dr Jay Abercrombie, Mogadore, Ohio, USA and especially William L. Murphy, Fishers, Indiana, USA for their detailed revisions of the manuscript. Finally, we thank Christine Devillers, Spa, Belgium for her translation of the English abstract into French.

\section{REFERENCES}

Abercrombie J. \& Berg C. O. 1975. - Natural history of Thecomyia limbata (Diptera: Sciomyzidae) from Brazil. Proceedings of the Entomological Society of Washington 77 (3): 355-368.

CURRAN C. H. 1934. - The Diptera of Kartabo, Bartica District, British Guiana, with descriptions of new species from other British Guiana localities. Bulletin of the American Museum of Natural History 66: 287-532.

FreY F. 1918. - Mitteilungen über südamerikanische Dipteren. Öfversigt af Finska vetenskaps-societetens förhandlingar 60: 1-35.

HeNDEL F. 1932. - Die Ausbeute der deutschen ChacoExpedition 1925/26. Diptera. (Fortsetzung). XXX-XXXVI. Sciomyzidae, Lauxaniidae, Tanypezidae, Lonchaeidae, Tylidae, Drosophilidae, Milichiidae. Konowia 11 (1): 98114, 11 (2): 115145.

Knutson L. V. \& Barros de Carvalho C. J. 1989. — Seasonal distribution of a relatively rare and a relatively common species of Thecomyia at Belém, Pará, Brazil (Diptera: Sciomyzidae). Memórias do Instituto Oswaldo Cruz 84 (4): 287289.

KNUTSON L. V. \& VAla J.-C. 2011. — Biology of Snail-Killing Sciomyzidae Flies. Cambridge University Press, Cambridge, 506 p.

KNUTSON L., Steyskal G. C., ZuSKa J. \& ABerCROMbie J. 1976. 64. Family Sciomyzidae, in PAPAVERO N. (ed.). A Catalogue of the Diptera of the Americas South of the United States, Zoological Museum, São Paulo, $24 \mathrm{p}$.

MARINONI L. \& MATHIS W. N. 2000. - A cladistic analysis of Sciomyzidae Fallén (Diptera). Proceedings of the Biological Society of Washington 113 (1): 162-209.

Marinoni L., Steyskal G. C. \& KNUTSOn L. V. 2003. - Revision and cladistic analysis of the Neotropical genus Thecomyia Perty (Diptera: Sciomyzidae). Zootaxa 191: 1-36.

Pascal O., Touroult J. \& Bouchet P. 2015. - Expédition «La Planète Revisitée» Guyane 2014-2015, Synthèse des premiers résultats. Muséum national d'Histoire naturelle; Pro-Natura International, 218 p.

Perty M. 1833. - Insecta brasiliensia, in PerTy M. (ed.), Delectus animalium articulatorum, quae in itinere per Brasiliam annis MDCCCX-MDCCCXX jussu et auspiciis Maximiliani Josephi I. Bavariae regis augustissimi peracto collegerunt Dr. J. B. de Sphix, et Dr. C. F. Ph. de Martius. Digessiti, descripsit, pingenea curabit Dr. Maximilianus Perty. F. S. Hübschmann, Munich \& Fleischer, Leipzig, 224 p. https://doi.org/10.5962/bhl.title.102991

Pollet M., Pascal O. \& Touroult J. 2014. - Flies from French Guiana: a unique opportunity. Fly Times 53: 3-6.

RONDANI C. 1868. - Diptera aliqua in America meridionali lecta a Prof. P. Strobel annis 1866-1867 distincta et annotata, novis aliquibus descriptis. Annales de la Società Naturale Modena 3: 24-40.

STEYSKAL G. C. 1966. — Notes on types of some species described in Sciomyza and Tetanocera by Loew, Walker and Van der Wulp (Diptera: Sciomyzidae, Muscidae, Neriidae, Pyrgotidae). Studia Entomologica 8 (14): 445-448.

Touroult J., Pollet M. \& PAscal O. 2018. - Overview of Mitaraka survey: research frame, study site and field protocols, in Touroult J., "Our Planet Reviewed" 2015 large-scale biotic survey in Mitaraka, French Guiana. Zoosystema 40 (13): 327-365. https://doi.org/10.5252/zoosystema2018v40a13. http://zoosystema.com/40/13

WALKER F. 1858. - Characters of undescribed Diptera in the collection of W. W. Saunders, Esq., F. R. S., \&c. Transactions of the Royal Entomological Society of London 4: 119-153.

WiedemanN C. R. W. 1819. - Brasilianische Zweiflügler. Zoologisches Magazin 1 (3): 40-56. 
